DOI: https://doi.org/10.31392/NPU-nc.series9.2018.18.06

UDC: $81^{\prime} 0$

Viktoriya O. Karlova

National Pedagogical Drahomanov University,

Kyiv, Ukraine

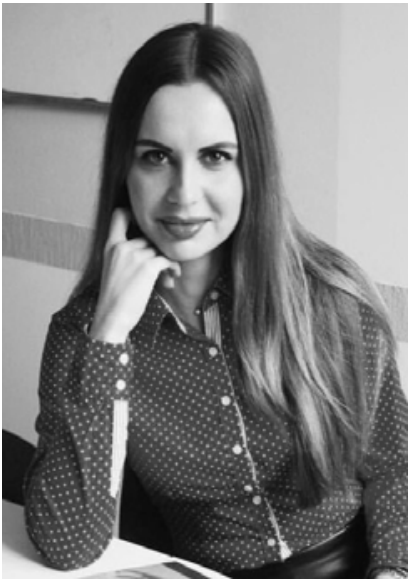

\title{
METHODOLOGY OF LANGUAGE CONTACT STUDIES AND THEIR RESULT - LEXICAL BORROWINGS
}

\section{Bibliographic Description:}

Karlova, V. O. (2018). Methodology of Language Contact Studies and Their Result - Lexical Borrowings. Scientific Journal of National Pedagogical Dragomanov University. Series 9. Current Trends in Language Development, 18. 74-86. DOI: https://doi.org /10.31392/NPU-nc.series9.2018.18.06

\footnotetext{
Abstract

The article is devoted to the study of those sociolinguistic processes, which became the main factors of the lexical borrowings appearance as the result of the language contacts in general and the English language contacts with other languages in different stages of the development in particular. It is described the process of new lexical units appearance, which adapting to the language-recipient, became the integral part of its vocabulary. It is defined the notion "Language Contacts" and its meaning for English inlargement. It is shown the methodological approaches for language contacts and borrowing process investigation. It is established the relation between such variants of linguistic contacts as bilingualism and interference, which contribute new lexical elements to the borrowing process. Types of interference are established which stimulate the borrowing process to English. Two main approaches (structural and sociological) were found to comprehend the process of language contacts and reveal ways of borrowed units adapting as the result of assimilation of the language of a new word. Available methods of lexical borrowing analysis are analyzed which had been developed by representatives of the structural approach (distributive analysis, component analysis, transformation analysis, oppositional analysis, semantic field analysis). Two types of factors, influencing borrowing processes within the limits of the sociological approach are characterized: 1) different social phenomena and 2) conscious society influence. Extralinguistic factors are found out which influence the increasing English vocabulary. It is defined the notions "Linguistic planning", "Linguistic construction", "Linguistic Politics". The scale of borrowing analysis (Thomason) is represented and it predicts the extent of interference and bilingualism (irregular, more regular and intense contacts). The developed methods for the adaptation analysis (non-adaptation) of new words in English are systematized by researchers, taking into account sociolinguistic and proper linguistic processes.

Keywords: borrowing, language contacts, lexical borrowing, structural and sociological approaches, social factors, structural method and its methods, adaptation of borrowing, interference, bilingualism, assimilation of borrowings, dihlossia.
} 


\section{Introduction.}

Modern globalization, as well as the close and constant contact of the languages during the study of general patterns and specific manifestations of their interaction, contributes to the successful organization of the communication process (Gudkov, 2003; Kulikova, 2006; Lebedeva, 1999; Pocheptsov, 2001; Salmina, 2001; Ter-Minasova, 2000 et al.).

In the conditions of the transcultural communicative space, intensification of the languages and cultures dialogue takes place (Pocheptsov, 2001; Salmina, 2001; TerMinasova, 2000; Ufimtseva, 2000; Chernyak, 2016; Khraban, 2016) the result of that is the lexical borrowing, because, as rightly had been noted by T. Kharban, "[...] borrowing processes reflect, on the one hand, changes in the life of each society, and on the other hand, - record the tendencies of the development of the lexical language system [...]" (Khraban, 2016: 139). It constitutes that the problem of mutual influence of languages remains the multiplicity and one of the most general and important topics of the modern linguistic research (Weinreich, 1979; Gudkov, 2003; Lebedeva, 1999; Martine, 1972; Rozenzweig, 1972; Salmina, 2001; Haugen, 1972; Scherba, 1974; Algeo, 2010; Thomason, 2001 et al.).

As the methodology of the research is oriented on the study of the borrowings analysis methods in English, the background of the general processes of the different languages contacting, we pay special attention to this particular language.

In the context of the outlined issue of the study of linguistic contacts which took place at different time intervals and their result - lexical borrowings, in particular during the development of the Old English language (Algeo, 2010; Jespersen, 1935; Singh, 2005), scholars began to search the causes and factors that influenced these processes.

Although the Old English language had been extended to a small territory and there was not literary standard at that time (Smirnitsky, 1998: 22), this did not become an obstacle to the penetration of the first wave of linguistic borrowings, which were necessary elements of the development of the English language for the reflection of socio-political, cultural, and economic processes for the transitional period of its functioning (Leleka, 2010: 7).

In the scientific space of Language Contact Studies the first who started to investigate the linguistic contacts and at the same time the processes of interference and bilingualism was Ascoli, Baudouin de Courtenay, Weinreich, Martine, Haugen and others (Vajnrajh, 1979; Haugen, 1972; Martine, 1972). The term "Linguistic Contact" was first introduced by A. Martine, subsequently U. Weinreich introduced it into the wide scientific use (Martine, 1972; Vajnrajh, 1979), who is considered to be the founder of Linguistic Contactology - the special area which studies issues of the languages influence (Vajnrajh, 1979: 2-27).

One of the variants of linguistic contact is the interference (Baudouin de Courtenay, 1963; Weinreich, 1979; Martine, 1972; Haugen, 1972 et al.), the condition of its became linguistic interaction (Vajnrajh, 1979; Martine, 1972; Haugen, 1972).

The term "Linguistic Interference" was initiated by the representatives of the Prague Linguistic Group, who addressed to the the issues of language unions, contacts and

interactions. Weinreich, who subsequently deepened the study of this problem, considered the concept of interference as "[...] deviation from the norms of some languages observed in communication [...] and causes changes in models as a result of the introduction of the foreign language elements into those spheres of language which are distinguished with the higher structural organization, for example, in the core of the phonemic system, in Morphology and Syntax, in some spheres of the dictionary [...]" (Vajnrajh, 1979: 22). This definition of the scientist became commonplace in all further scientific studies devoted to the study of the problems of language contacts.

Another methodological problem in the field of linguistic contacts is connected with the process of bilingualism. Scherba identified two possible forms of bilingualism at one 
time. The first form is when a person belongs to two opposing different language groups and uses a certain language for communication in each of them. Languages in this case can not be used together. This is the so-called "pure" bilingualism. The second form is determined by people who officially use one language, and in everyday life - another. Such bilingualism is called "mixed" by Shcherba, because there is the mixing of languages (Shcherba, 1974: 314). So, based on this differentiation, we might consider that pure bilingualism is bilingualism, and interference is mixed. The methodology for linguistic analyыing contacts develops whithin both processes, showing which principles will help to determine as its effectiveness as prospects of development.

\section{Aim.}

The aim of the article is to describe the methodology which had been developed by the researchers for the investigation of language contacts and their result - lexical borrowings in the English language in various stages of its development.

\section{Methodological Approaches of the Borrowing Investigation Process.}

One of the first researchers of the XX century, who was interested in the issue of language contacts, as it has been already mentioned, was Weinreich, having written the monograph called "Language Contacts", where two main methodological approaches of the study of this sociolinguistic phenomenon were pointed out: 1) sociological, which, in his opinion, is connected with the fact that the transfer of vocabulary from one language to another is due to the cultural environment, and 2) structural, on the basis of which the language is perceived as new elements transmitted through other languages, as well as changes as a result of what is happening in the language (Vajnrajh, 1979: 184-186).

The structural approach was further developed in the framework of descriptive linguistics in the works of the Prague phonologists (Jacobson, 1935) at the end of the XX century - beginning of 30-s, who had solved the problem of interference (Jacobson, 2011: 197). They agreed with Weinreich who adhered to the ideas of structuralism that the transfer of linguistic features from one language to another was a process of general language change. Accordingly, every language is considered to be in exposition to potential interference originating from neighboring languages. And at first the scientists were focused on studying the structural issues of language contacts, but the social sphere was not at the time deeply meaningful, although Weinreich noted that since the end of the XIX century attempts were also made to explain the causes of linguistic contact with the socio-cultural environment (Vajnrajh, 1979: 27, 31, 103, 83-84).

In the opinion of Weinreich, in the course of time, Martine united epy sociological and structural approaches (Martine, 1972; Vajnrajh, 1979: 184-186), because, according to his observations, when it applies even to unpopulated pre-territory, there is the possibility that the new environment and way of life will determine the development of speech in the area, and directly and the language in general. As a rule, the language spreads through the bilingual situation, which, regardless of whether the language continues its existence after the linguistic confrontation or the disappearance of one of the two, always greatly affects the language (Martine, 1972). It was quite correct that his assumption was that "[...] language is not the coincidence of words and sounds, but it is clearly organized by the whole [...]" (Martine, 1972), and therefore "[...] the structure of language must be understood as the stable systemic-structural formation in its dynamics (Martine, 1972)".

Martine assumed that, with the contact of languages, certain number of people would be forced to use two language systems in the course of their communicative activities, and as a result, the influence of one system on another would arise (Martine, 1972). The main thing is that these changes are not possible without the activity of the linguistic community, 
because "[...] society is not homogeneous and hardly has ever been closed (Martine, 1972)". The scientist explained this methodological necessity of combination of two approaches with the language influence analysis. If the structural approach allows to analyze language changes from the standpoint of the general structure of the language, the reasons for these changes should be analyzed already in the aspect of the sociological approach as the possible influence of another language in these changes of the contact language structure (Martine, 1972).

Another methodological approach for studying the process of language influences was suggested by Rosenzweig, who had distinguished the "microscopic approach" of their analysis - the synchronous study of the phenomena of linguistic contact, and the "macroscopic approach", that is, the diachronic analysis of the language interactions results.

The researcher noted that the simulation of the process of changing contact languages in synchronization and diachrony has common features: the first approach is aimed at describing the process of interference with analyzing the language of bilingual individuals, including the experimental facts obtained with psychological methods. The second approach - the process of convergence of contact languages is verified with historical facts (Rozencvejg, 1981).

The appropriate methodology was developed directly for the analysis of speech interference, which included methods for analyzing of various types of it: phonetic, grammatical and lexical interference.

Phonetic interference is associated with the transfer of pronunciation from one language to another. It is the sound substitution that allows to perceive linguistic units without altering the secondary phonemic system. With regard to grammatical interference, it arises only when "[...] rules of grammatical units which are the part of the system of another language adapt to the rules of the language grammar" (Vajnrajh, 1979: 36). According to Weinreich, the result of grammatical interference is the identification of morphemes, syntactic constructions or grammatical categories of two languages on the basis of their formal similarity or functional similarity (Vajnrajh, 1979: 74). As a result, the grammatical model with invariant forms wins during long contact between two (Vajnrajh, 1979: 76).

The lexical interference is due to the lack of specific words to refer to the phenomena of being (Vajnrajh, 1979: 40). Weinreich developed even the typology of lexical interference. The first type is represented with the direct transfer of the phoneme sequence from one language to another without changing the meaning of the word; the second is the expansion of the sphere of use of the specific word on the model of another word, on the basis of which the transfer of value occurs; the third type is the change of the language sign expression plan with analogy and its congregation (single-word) in the contact language without changing in the content plan.

As for the lexical interference of complex words and phrases, it causes such processes as the adaptation of the components of a complex word or phrase to the word-formation or syntax models of the language-recipient; the reproduction of complex words and phrases is also done using specific equivalent words. This type of lexical interference Weinreich called replication and singled out the different types (actually replications, explanation replications, formation replications) (Vajnrajh, 1979: 83-89).

However, there is another Haugen's approach of the interference analysis, which divides two contact languages, calling them P - "primary" and S - "secondary", and he suggests that the switching of codes in the direction from $\mathrm{P}$ to $\mathrm{S}$ and back is not interference, as there is no interference and the material of the language $\mathrm{P}$ in the language $\mathrm{S}$, which was completely assimilated to it (Haugen, 1972). This view is more closely connected with the results of language contacts and their adaptation (non-adaptation) in the language. 
Proceeding from the understanding of various types of interference process as the problem of linguistic contact, it becomes necessary to investigate the result of the interactions of language borrowings, particularly their lexical layer, which enlarge the vocabulary of each language with the new components and English as well.

\section{Methodological Approaches of the Results of Language Contacts Studying.}

Since the linguists had been involved into the borrowed lexical units, the problem of the methods development for their analysis appeared. And even then I. Baudouin de Courtenay expressed the opinion that in general methods of research in linguistics should approach to the methods of exact sciences; "[...] it is necessary to describe the language on the basis of statistical calculations, introduce the concept of small quantities for the calculation of differences between languages, etc. [...]" (Baudouin de Courtenay, 1963: 8), which in one way or another relate to the development of adequate methods of analysis, differentiation and quantitative and statistical calculation in the contact languages of lexical borrowings.

The methodological principles of borrowing research were formed on the basis which has been already mentioned, also the structural approach and the methods which were used mainly for the analysis of methods of adapting borrowings in general and lexical in particular, including the sociological approach.

\subsection{Structural Approach and its Methods for the Adapting Process Analysis of Borrowings in English.}

Representatives of the first approach used structural analysis techniques, including distributive analysis, component analysis, transformation analysis, opposition analysis, semantic fields, which, according to many contemporary researchers (Eldarov, 1984; Sapranova, 2002; Timofeeva, 2005 et al.) were effective and appropriate to detect changes in English after the emplementation of new elements into it.

The main issue after the penetration of borrowing was due to the discovery of whether the new lexical unit (Bogachenko, 2003; Volodina, 2007; Eldarov, 1984; Sapranova, 2002) "got accustomed" to the new English language environment. The verification of this task was carried out with the help of traditional structural methods in order to identify different processes of adapting borrowings in English.

The distributive analysis was used to identify the processes of phonetic (Bogachenko, 2003; Sapranova, 2002), graphic (Bogachenko, 2003; Eldarov, 1984; Sapranova, 2002), grammatical (Bogachenko, 2003; Eldarov, 1984; Proshina, 2002; Sapranova, 2002; Timofeeva, 2005), semantic (Bogachenko, 2003; Eldarov, 1984; Karimova, 2013), phonographic (Eldarov, 1984; Proshyna, 2002) adapting, and identify the differential characteristics of debt and their changes after acquiring lexical units adaptation in English.

As a result of these studies (Bogachenko, 2003; Proshyna, 2002; Timofeeva, 2005 et al.), it was concluded that not only the borrowing changes the structure, but even the English language has certain lexical, semantic and grammatical transformations (Bogachenko, 2003; Sapranova, 2002; Eldarov, 1984; Proshina, 2002; Timofeeva, 2005; Karimova, 2013).

The methodology of structural analysis method was the analysis of semantic fields, which also was effectively used for the researching of the new vocabulary, including determining of the minimum significant element - sema. And for this, as a rule, component analysis was used. In works of Bitco and Proshina's with the following method, the borrowing was combined on the basis of its conceptual, functional and substantive similarity to the all-encompassing field, which was interpreted as the linguistic and cultural field of borrowing in the English language. In the process of this analysis Proshina revealed the national-cultural component of the semantics of Chinese, Korean, Japanese borrowings in 
English. The same technique was used in the study and it also was found semantic borrowings from German, Dutch, Spanish, French into English by Taganova (Taganova, 2003; Proshina, 2002; Bitco, 2008).

That analysis of semantic fields became crucial for the implementation of component analysis method, with the help of which borrowed lexical units were decomposed into minimal values - semas for their further semantic classification and analysis. As a result, researchers systematized thematic-semantic blocks of new words to the English language (Bitko, 2008; Ganieva, 2010; Karimova, 2013; Kotov, 2003; Mikheeva, 2010).

This technique was proved as effective in the study of Sapranova for the study of the changes in the semantic structure of mono- and polysemantic lexemes of German origin in the English language. The changes of the new vocabulary, their evolution and word-forming models of German borrowings were analyzed. As a result, it was found the tendency of German borrowing assimilation in the lexical-semantic system of English subject to the general rules of the system: only those words adapt from the new vocabulary which denote essential objects and phenomena, wholly or partially replaced because of the influence of phonetic or lexical peculiarities of the English language.

Mikheeva also noticed such tendencies for the French borrowings and suggested that in the English language contacts there are the significant semantic changes and plurecentrisms which are the main characteristics of modern English and this is manifested in the existence of different regional variants associated with the interference (Mikheeva, 2010; Proshina, 2002; Sapranova, 2002).

For analysis the phonetic borrowings adaptation in English, researchers used actively the oppositional analysis, in particular to identify different variants of phonetic changes, when the same phoneme can be implemented in several sounds depending on its lexical environment. Eldarov used such analysis to identify changes in the Italian language, concluding that these borrowings are monosemantic (87\%) mostly, but only a small part of the new vocabulary (13\%) in English turned polisemantic (Eldarov, 1984).

Transformational analysis as an integral part of the structural method has been tested in the scientific research of Timofeeva, who investigated the grammatical transformations in the translation of the secondary predicate constructions, and noticed that the highest degree of interference was manifested in constructions where the Latin language and the Old English language were similar. In general, the Latin influence contributed to the more intensive use of syntactic models in such situaton which was also existed in the Old English language, as well as the emergence of new models with analogy (Timofeeva, 2005).

The preliminary and review of the works where the complex methodology of the structural method was used to analyze the adaptation processes of borrowings in English gives grounds to claim that as a result of linguistic contacts these units complemented the English vocabulary in the field of scientific terminology, English literature and life.

Three levels of borrowing adaptation were presented as: 1) partially adapted, 2) unadapted and 3) fully adapted (Bogachenko, 2003).

As the adaptation is considered as the complex process of difficult words adapting to the new language, but the assimilation refers to more phonetic assimilations of one sound to another (Slovnik ukrains'koi movi, 2018), then in the English language scientific sources (Baugh, 2002; Cable, 2002; Piltz, 1981; Singh, 2005 et al.) terminologically and conceptually both processes are different, where "adaptation - a process of changing to suit different conditions [...]" and meanwhile "assimilation - the process of becoming a part [...]" (Cambridge dictionary, 2018).

However, we have to determine that in most of the scholarly works which are devoted to these processes, both terms are used as synonyms (Bogachenko, 2003; Komarov, 2007; 
Eldarov, 1984 et al.). In our opinion, assimilation concerns the phonetic adaptation, while the adaptation deals with the grammatical adaptation.

Conditionally, this can be defined as the gradual stages of the entry of the new vocabulary into the language-recipient, where the first stage is assimilation, and the next one is the adaptation of the new vocabulary, that is, the penetration of the new word into another language, and subsequently its adaptation to the structure of another language. At the last stage it is determined whether new words will be coped with the specific vocabulary or will be taken forever from the use of the language (Bogachenko, 2003; Komarov, 2007; Eldarov, 1984; Cable, 2002; Piltz, 1981; Singh, 2005).

U. Weinreich referred these questions to the tasks of the sociological approach in the borrowings study. The scientist distinguished three complexes of relevant factors which influence both lexical borrowing processes: extralinguistic (sociolinguistic), internal (psycholinguistic) and actually linguistic (Vajnrajh, 1979).

\subsection{Sociological Approach and its Methods for the Influence Factors of the Lexical Borrowings Adaptation in English.}

As each language, including English, is the social phenomenon, then its functioning, as Mirsaminova suggests, and it is worth agreeing with, is closely connected with the life of society at the various stages of its development (Mirsaminova, 2017: 117).

During the history of English, according to Komarova, there were many changes, as political and social, and which influenced on the functioning and development of the lexical fund of the English language significantly. In general, factors influenced differently, each of which had certain features that distinguish them from each other (Komarov, 2007).

$\mathrm{Jh}$. Algeo called these factors as extralinguistic and defines them as: the parameters of extra-language social activity, which predetermine changes in language, both global and partial (Algeo, 2010). Borrowings can also be attributed to sociological (more sociolinguistic) factors of influence on linguistic changes, which made the language progresse. Therefore, learning language not only from a linguistic point, but also from a social approach, we are convinced that language is not the closed system, it is open to external influences (Bersyrov, Bersyrova, 2016: 44). During the process of new elements borrowing, external, extralinguistic causes are of paramount importance, while internal, linguistic factors begin to influence a little later - in the process of borrowings adapting to the new language environment (Bogoslovskaya, 2003).

Obviously, the language is changing and evolving continuously (Bercyrov, Bersyrova, 2016), but the influence of society is not always the same or homogeneous. Different social factors affect the new lexical elements, especially their adaptation to the language-recipient. There are two types of influence: 1) the influence of social factors on linguistic processes, caused with the logic of social development, and 2) the conscious influence of society on the development, functioning of lexical elements and their interaction with other linguistic elements (Bersyrov, Bersyrova, 2016: 44).

Under the influence of society we consider with Bersyrova, the conscious influence on the functioning and development of the language, which manifests itself at different levels and in various forms, in particular, such as: society can contribute to the development of language or the gradual release of words of use; society can expand the social functions of the language with creating writing, organizing learning, publishing literature, etc; possible improvement and normalization of sound composition, morphological, syntactic, stylistic, lexico-grammatical systems of language; society has the right to regulate the processes of the languages interaction and regulate foreign language borrowing, etc. (Bersyrov, Bersyrova, 2016: 45). 
With regard to the last factor of influence, it is necessary to take into account the fact that there are certain limits that block foreign language borrowings, contributing to the "protection" of the native language. Scholars paid attention to this and made the linguistic theory in language communication as the "language policy". Schweizer defines this term as: "[...] the set of measures taken by the state and society to change or maintain the functional distribution of languages or linguistic subsystems with respect to the introduction of new and sustainable linguistic norms [...]" (Schweizer, 1987: 117). Of course, appropriate methodological tools have been developed for this purpose.

According to Schweizer, there is also the notion of "linguistic planning" and "linguistic construction", which are directly related to "linguistic politics". He defines "linguistic planning" as the concerns the conscious and purposeful factors of influence on language. Thus, "linguistic construction" is one of the elements of "language policy", and therefore the notion of "linguistic construction" and "linguistic politics" are related to each other as part of the whole.

Direct functions of "language policy", according to Bercyrov, Bersyrova et al. related to the functional side of the language. "Language policy" is the deliberate process that studies language dynamics through concrete, predominantly experimental methods, including the sociolinguistic experiment that involves studying the tasks of "language policy" and an analysis of the implementation of "language policy". We are convinced that among these tasks of the sociolinguistic experiment there is a place for analysis of adaptation or non-adaptation of borrowings, since the state also regulates the process of entering new elements into the language (Bersyrov, Bersyrova, 2016: 47).

On the other hand, conditions should be created, conversely, contribute to the processes of borrowings adapting. Kochurova, guided by hes scientific observations, suggests that the sociolinguistic analysis should include the identification of such factors as "[...] the presence of contact of culture and society (language contact); the certain level of bilingualism; the quantitative link of contact communities; intensity and duration of contacts; the degree of bilingualism in two languages; the functional significance of both languages in the life of bilingual society, the status and prestige of contact languages and cultures; assessment and relation to multi-linguistics, as well as the interference that accompanies this phenomenon [...]" (Kochurova, 2010: 148).

The analysis of these factors allows to predict the extent of interference and borrowing. Thomason developed the schedule for borrowings analyzing in his work "Language Contact", which identified: 1) irregular contacts, resulting in single lexical borrowings, mainly the Nouns, less often Verbs, Adjectives or Adverbs (Thomason, 2001: 70); 2) more regular contacts - bilingual individuals are well aware of the source language but they are the minority among the speakers of the language-recipient. Lexical borrowings include both functional words (Conjunctions, Adverbial particles) and meaningful ones (Thomason 2001: 70). During more regular contacts the number of bilingual individuals increase and social factors contribute to borrowings; 3 ) intense contacts which are characterized by the high percentage of bilingual individuals among speakers of the language-recipient, where social factors favorably affect borrowing - lead to the large number of borrowings in all spheres of vocabulary; the structural borrowing also takes place, which leads to serious typological changes in the language-recipient. Thus, the whole phonetic categories appear or disappear; some changes affect even the substitute for agglutinating fungal Morphology, or vice versa (Thomason, 2001: 70).

It should be noted that in the conditions of diglossia, it can lead to linguistic "death", and in the conditions of bilingualism, to linguistic convergence and the appearance of 
pidgins (simplified language as means of communication between two or more ethnic groups) or Creole (Timofeeva, 2005: 33).

The conscious influence of society is also closely connected with the influence of social factors, among which: trade-economic, political, cultural, religious, domestic, governing assimilation processes and adapting borrowings. There is also the territorial fact of influence, that is, the neighboring location of countries. For example, Anglo-Saxons and Scandinavians co-existed peacefully before the Scandinavian invasions, as the result the new words penetrated into English (Mirsaminova, 2017: 121).

However, according to Volnova's observations, it can be noted that the ability of the English language to borrow words was that "[...] Britain was constantly in direct contacts with neighboring countries, which eventually contributed to the spread foreign language words in its territory. The influence of one language or another can always be linked to historical factors, including various conquests, trade, wars and many others [...]" (Volnova, 2014). All these reasons determine the different intensity of borrowings, depending on the circumstances in one or another period of time (Volnova, 2014).

Sarangyeva also agrees that the borrowings of lexical elements from one language to another is the very ancient phenomenon and is known in the languages of the prehistoric world. She assumes that "[...] for the borrowed words in the new language, it is very important which words they got into with [...]" (Sarangyeva, 2015: 23).

As for English, Volnova suggests that the English vocabulary has been constantly changing throughout history. "One of the borrowing problems that came to English is their number, which is quite large compared to other languages [...]" and which represent more than fifty percent of the total vocabulary, and the rest in it are the specific English words and expressions (Volnova, 2014).

In addition to historical factors, the influence of science and technology was powerful when it came to the English language in terms of scientific and technical terms (Komarov, Mirsaminova), first of all, since the long period of their development.

It should also be said that "[...] borrowings in the Old English language were due to the presence of lacuna in its lexical system, that is, the absence of the necessary names for the expression of new concepts and objects. The Old English language, perceiving words, corresponds to the notions for which it has no signs, borrowed both the concept and the very name [...]" (Tukalevskaya, 2008: 246).

All this suggests that the causes of contact-induced changes exist not only in the structure of interrelated languages, but also outside of it. For the most part, the same linguistic material in different languages acquires the opposite transformations, which is associated with many non-linguistic factors (Kochurova, 2010: 148).

In order to understand why some borrowings are fully adapted and others disappear, methods should be identified to help first analyse the ways in which they are assimilated to a new language and, as a consequence, subsequently their adaptation or non-adaptation.

At one time the researchers used the elements of the comparative-historical method to reconstruct the historical factors that led to the entry of borrowings into a new language due to the presence of lexical gaps very successfully. In particular Timofeeva directed this method on the analysis of those extra-linguistic factors which had influenced the adaptation of new words in the Old English language. The researcher believes that the linguistic interference and bilingualism, due to writing and religion, directed the Old English language to the assimilation of Latin words due to the lack of their own terms and concepts that were necessary at that time. Although the Anglo-Saxons resisted the new vocabulary, however, they were forced to adapt new words to fill lexical gaps, which have come from different fields and sources in other languages (Timofeeva, 2005). 
Using this method, and the comparative-typological method and the method linguogeography Sapranova determined the degree of adaptation depends on different reasons, including genetic kinship of languages, typological similarity, frequency of use of the borrowed units, duration of use of the word, the degree of intensity assimilating the influence of the language-recipient. The main condition, in its view, should be bilingualism, where a foreign word is first used in the bilingual environment, and then extended to the wider language industry (Sapranova, 2002).

In addition, as it has already been mentioned, the researchers applied methods of structural techniques (Bogoslovskaya, 2003; Kotov, 2003; Lantsova, 2006; Taganova, 2003 et al.) to explain the borrowing characteristics at the certain stage of language development. For example, Taganova, analysing the factors of influence on American English, found that the process of borrowing occurs in two cases: 1) during the penetration into the culture of the recipient of the new concepts, and 2) when entering the culture of the recipient of the new concept. Mostly the reasons for linguistic borrowing is due to lack borrowed the culture concept, and therefore, the certain concept (Taganova, 2003).

The structural method as the component analysis is very effective in this technique, which, spreading the words in semas, can determine a new word which group borrowings belong to: domestic, religious, political, ritual vocabulary, etc. (Bitco, 2008; Lantsova, 2006; Proshina, 2002; Taganova, 2003 et al.).

It gave them reasons to identify the social factors that contributed to the occurrence of borrowed lexical units of the language-recipient at different stages of the English language development, that is, to show the areas of life where the lack of new concepts or terms.

Krasnikova and Bogoslovskaya used the component analysis together with the semantic one in order to trace spheres to enhance the impact of new words and "neologic" lexical units that came out at the time of use, and in general to identify extra-linguistic factors that led to the emergence of such linguistic processes (Krasnikova, 1994; Bogoslovskaya, 2003).

Exploring German loanwords in the English language, I. Sapranova found the tendency to expand semantic structures: some borrowed words at the present stage of development of the English language have already been used in the indirect sense which were borrowed for other purposes before and used in the direct meaning (Sapranova, 2002).

Also to determine the social factors influencing new lexical items and their further adaptation (non-adaptation), it was received the new linguistic method of psycholinguistic analysis (Kocherhan, 2006), which can reveal unconscious perception (denial) of new words by society. These subliminal (cognitive) processes provide an opportunity to explain why some elements, falling to the language, effectively survive and operate while others disappear forever (Krasnikova, 1994).

\section{Conclusions.}

In conclusion, we note that contemporary globalization and the constant language contacts, which are bilingualism and interference, actualize the appearance of borrowings in different languages, particularly in English. Borrowings came in the speech at different historical stages of their development. According to the English language, this issue remains debatable and controversial in terms of its borrowings in the Old English period. However, observations show that although the Old English was spoken in the small area and did not have the single literary standard, it did not prevent the penetration of new words in the lexical structure of the language, which is not permanent and is constantly changing throughout its history. There were developed two approaches for analyzing these processes: the sociological and structural analysis for borrowings. Representatives of the structural approach used structural methods (distribution analysis, componential analysis, 
transformational analysis, opposition analysis, analysis of semantic fields) for the study of new vocabulary, which was allowed to identify different degrees of adaptation to the language-recipient (non-adapted, partially adapted, fully adapted).

The sociological approach helped to identify two main factors influencing the process of adaptation of lexical borrowings in general and English in particular: at first, that social factors impact directly on language contact (conquest, war, trade, religion, etc.), and then social factors which determine the further conditions of adaptation (non-adaptation) of borrowings ("language policy").

\section{References}

Algeo, Jh. (2010). The origin and development of the English language. Wadsworth: Cengage learning.

Baugh, Al., Cable, T. (2002). A history of the English language. L. : Pearson.

Bersirova, S. A., Bersirov, T. B. (2016). Sociolingvisticheskie faktory vozdejstviya na yazyk [Sociolinguistic factors affecting the language]. Vestnik $A G U, 3$ (184), 43-47.

Bitko, N. S. (2008). Zapozichennya yak sposib adaptaciï konceptual'noï i leksichnoï sistemi anglijs'koï movi do al'ternativnoï real'nosti [Borrowings as the Adaptation Method of Conceptual and Lexical System of English to Alternative reality]: Thesis: 10.02 .04 . Odesa.

Bogachenko, N. G. (2003). Istoriya vostochnoaziatskih zaimstvovanij v anglijskom yazyke: na materiale Bol'shogo Oksfordskogo slovarya [History of West Asian Borrowings in English: Based on the Big Oxford Dictionary]: Thesis: 10.02.04. Vladivostok.

Bogoslovskaya, V.R. (2003). Strukturno-semanticheskaya i funkcional'naya adaptaciya zaimstvovanij: na materiale sportivnoj leksiki anglijskogo i russkogo yazykov [Structural-semantic and Fucnctional adaptation of Borrowings: Based on Sport Vocabulary of English and Russian]: Thesis: 10.02.19. Volgograd.

Buduen de Kurtene, I. A. (1963). Izbrannye trudy po obshchemu yazykoznaniyu [Special Works of General Linguistics]. M. : Izdatel'stvo akademii nauk SSSR.

Cambridge dictionary. (2018). Retrieved from https://dictionary.cambridge.org

Chernyak, N. V. (2016). Mezhkul'turnaya kompetenciya: istoriya issledovaniya, opredelenie, modeli i metody kontrolya: monografiya [International competence: the history of investigation, notion, models and methods of the control: monograph]. M. : Flinta.

El'darov, A. M. (1984). Ital'yanskie zaimstvovaniya $v$ sovremennom anglijskom yazyke (Doctoral dissertation). [Italian Borrowings in Modern English]: Thesis: 10.02.04. Leningrad.

Ganieva, G. R. (2010). Frazeologicheskie edinicy s komponentom imenem sobstvennym v anglijskom, russkom i tatarskom yazykah [Idioms with Component Name in English, Russian, Tatar]: Thesis: 10.02.20. Kazan.

Gudkov, D. B. (2003). Teoriya i praktika mezhkul'turnoj kommunikacii: kurs lekcij [Theory and Practice of International Communication]. M.: ITDGK "Gnozis".

Haugen, E. (1972). Yazykovoj kontakt [Language Contact]. Novoe v lingvistike. 6, 61-80.

Hraban, T.E. (2016). Leksicheskoe zaimstvovanie kak rezul'tat mezhkul'turnoj i mezh'yazykovoj kommunikacii [Lexical Borrowing as Result of Intercultural and Interlanguage Communication]. Repozitorij VGU, Uchenye zapiski, 21, 138-143.

Jespersen, O. (1935). Growth and Structure of the English Language. Leipzig: B.G. Teubner; New York, G.E. Stechert \& Co.

Karimova, G. F. (2013). Strukturno-semanticheskie osobennosti russkih zaimstvovanij v anglijskom yazyke [Structural-Semantic Peculiarities of Russian Borrowings in English]: Thesis: 10.02.20. Dushambe.

Kochergan, M. P. (2006). Zagal'ne movoznavstvo [General Linguistics]. K. : Akademiya.

Kochurova, Yu. N. (2010). Ekstralingvisticheskie usloviya kak faktor internacionalizacii [Extralinguistics conditions as internationalization factor]. Vestnik Udmurdskogo universiteta, 2, 145-149.

Komarov, G. V. (2007). Nacional'no-kul'turnaya specifika novoj leksiki anglijskogo yazyka [NationalCultural Specification of New Vocabulary in English]: Thesis: 10.02.19. Krasnodar.

Kotov, G. G. (2003). Vliyanie vneshnih faktorov na funkcionirovanie i razvitie leksicheskogo sostava yazyka [Influance of Interior Factors of Functioning and Development of Lexical Vocabulary]: Thesis: 10.02.19. S-Peterburg.

Krasnikova, E. Yu. (1994). Vliyanie sovremennyh obshchestvenno-politicheskih faktorov na razvitie $i$ funkcionirovanie social'no-ocenochnoj leksiki russkogo yazyka [Influence of Modern Social and Political Factors on Development and Functioning of Socially-Evaluation Vocabulary of Russian]: Thesis: 10.02.04. Moskva. 
Kulikova, L. V. (2006). Kommunikativnyj stil' v mezhkul'turnoj paradigm: monografiya [Communicative style in the international paradigm: monograph]. Krasnoyarsk : KGPU im. V. P. Astaf'eva.

Lancova, L. K. (2006). Ekstra- i intralingvisticheskie faktory formirovaniya zhargona narkomanov $v$ anglijskom yazyke [Extra and Inrolinguistics Factors of Forming of Jargonof Drug Addicts in English]: Thesis: 10.02.04. Saratov.

Lebedeva, N. M. (1999). Vvedenie v etnicheskuyu i kross-kul'turnuyu psihologiyu [Introduction to Ethnic and Cross-Cultural Psychology]. M. : Klyuch-S.

Leleka, T. O. (2010). Osoblivosti angloamerikans'kih zapozichen'v ukraïns'kij i rosijs'kij movah na pochatku XXI stolittya na tli procesu kontaktuvannya mov (na materiali slovnikiv ta movi ZMI) [Features of the AngloAmerican borrowings in the Ukrainian and Russian languages at the beginning of XXI century on the background the process of contact of languages (based on the dictionaries and the Mass-Media language]: Thesis: 10.02.20. Kyiv.

Martine, A. (1972). Rasprostranenie yazyka i strukturnaya lingvistika [Distribution of Language and Structural Linguistics]. Novoe v lingvistike, 6, 81-93.

Miheeva, M. I. (2010). Francuzskie zaimstvovaniya $v$ anglijskom yazyke XVI - XVIII vekov $i$ problemy perevoda [French Borrowings in English XVI - XVIII Century and Translation Problems]: Thesis: 10.02.20. Moskva.

Mirsaminova, G. M. (2017). Faktory zaimstvovaniya yazykovyh edinic [Factors of Language Units Borrowings]. Vestnik Tadzhikskogo gosudarstvennogo universiteta prava, biznesa i politiki. Seriya gumanitarnyh nauk, 116-124.

Piltz, A. (1981). The World of Medieval Learning. Oxford : Blackwell.

Pochepcov, G. G. (2001). Teoriya kommunikacii [Theory of Communication]. M. : Refl-buk, K. : Vakler.

Proshina, Z. G. (2002). Anglijskij yazyk kak posrednik v kommunikacii narodov Vostochnoj Azii i Rossii: problemy oposredovannogo perevoda [English as the Mediator in Communication of People of East Asia and Russia: Problems of the Mediated Translation]: Thesis: 10.02.20. Vladivostok.

Rozencvejg, V. Yu. (1972). Yazykovye kontakty [Language Contacts]. L. : Nauka.

Rozencvejg, V. Yu. (1981). Uproshchenie leksiko-semanticheskoj sintagmatiki pri yazykovom kontakte [Simplification of Lexico-semantic Syntagmatics at the Language contact]. Teoriya yazyka, metody ego issledovaniya i prepodavaniya: $k$ 100-letiyu so dnya rozhdeniya L'va Vladimirovicha Shcherby. 229-233.

Salmina L. M. (2001). Kommunikaciya. Yazyk. Myshlenie: monografiya [Language. Intellection: monograph]. Kazan': DAS.

Sapranova, I. L. (2002). Zaimstvovanie i osvoenie nemeckih slov anglijskim yazykom: v period s 1930 po 2000 gody [Borrowing and Mastering of the German Words of English: in a Period from 1930 to 2000]: Thesis: 10.02.04. Moskva.

Sarangaeva, Zh. N. (2015). Rol' zaimstvovanij v anglijskom yazyke [Role of Borrowings in English]. Vestnik Kalmyckogo universiteta, 3, 22-26.

Shcherba, L. V. (1974). Yazykovaya sistemi i rechevaya deyatel'nost' [Language Systems and Speech Activity]. Leningrad : Nauka.

Shvejcer, D. A., Nikol'skij, L. B. (1987). Vvedenie v sociolingvistiku [Introduction to Social Linguistics]. M. : Vyssh. shkola.

Singh, I. (2005). The history of English. L. : Hodder education.

Slovnik ukrains'koi movi. (2018). Akademichnij tlumachnij slovnik (1970-1980 rr.) [Academic Explanatory Dictionary]. Retrieved from http://sum.in.ua

Smirnickij, A. I. (1998). Drevneanglijskij yazyk [Old English]. M.: Filologicheskij fakul'tet MGU im. M. V. Lomonosova.

Taganova, T. A. (2003). Zaimstvovaniya $v$ amerikanskij variant anglijskogo yazyka: kul'turologicheskij $i$ leksikograficheskij aspekty [Borrowings as American Variant of English: Cultural and Lexical-Graphics aspects]: Thesis: 10.02.04. Ivanovo.

Ter-Minasova, S. G. (2000). Yazyk i mezhkul'turnaya kommunikaciya [Language in the International Communication]. M. : Slovo/Slovo.

The Cambridge History of the English Language [The Cambridge History of the English]. (1992). Cambridge : Cambridge University press.

Thomason, S. G. (2001). Language Contact. Edinburgh: Edinburgh University press.

Timofeeva, O. V. (2005). Sintaksicheskie zaimstvovaniya v drevneanglijskom yazyke [Syntex Borrowings in Old English]: Thesis: 10.02.20. S-Peterburg. 
Tukalevskaya, N. Yu. (2008). Zaimstvovanie kak odin iz sposobov kul'turnoj adaptacii yazyka [Borrowing as One of the Methods of Cultural Language Adaptation]. Vestnik Nizhegorodskogo universiteta im. N. I. Lobachevskogo, 5, 246-249.

Ufimceva, N. V. (2000). Etnicheskij harakter, obraz sebya i yazykovoe soznanie russkih [Ethnic Character, Image and Language Consiousness of Russions]. Yazykovoe soznanie: formirovanie i funkcionirovanie: sb. statej. $135-170$

Vajnrajh, U. (1979). Yazykovye kontakty [Language Contacts]. K. : Vishcha shkola.

Vol'nova, D. N. (2017). Inostrannye zaimstvovaniya kak odin iz istochnikov slovarnogo sostava anglijskogo yazyka [Foreign Borrowings as One of the Sourches of English Vocabulary]. Retrieved from http://web.snauka.ru/issues/2014/12/39354

Volodina, E. G. (2007). Leksicheskie zaimstvovaniya iz anglijskogo yazyka v sovremennom tureckom yazyke: na materiale periodiki [Lexical borrowings of English in the Modern Turkish Language Based on Periodicals]: Thesis: 10.02.22. Moskva. kul'tur.

Yakobson, R. (2011). Formal'naya shkola i sovremennoe russkoe literaturovedenie. M. : Yazyki slavyanskih

\section{Бібліографічний опис:}

Карлова, В. О. (2018). Методологія вивчення мовних контактів та їх результату - иексичних запозичень. Науковий часопис Національного педагогічного університету імені М. П. Арагоманова. Серія 9. Сучасні тенденції розвитку мов, 18. 74-86. DOI: https://doi.org/10.31392/NPU-nc.series9.2018.18.06

\section{Анотація}

Стаття присвячена вивченню тих сочіолінгвістичних процесів, щуо стали головними факторами появи лексичних запозичень як результату контактування мов загалом та контактування англійської мови з іншими мовами на різних етапах розвитку зокрема. Описано процес появи нових лексичних одиниць у мові-реципієнті, які адаптуються $і$ стають складовою частиною ї̈ словникового складу. Визначено поняття “мовні контакти” $i$ його значення для збільшення словникового складу давньоанглійської мови. Представлено методологічні підходи для вивчення мовних контактів і процесу запозичень. Установлено співвідношення між такими варіантами мовного контактування, як білінгвізм та інтерференція, щзо сприяють процесу запозичень нових лексичних елементів. Визначено типи інтерференції, щуо слугують поштовхом появи нових слів у англійській мові. Виявлено два основні підходи (структурний і соичілогічний) до осмислення процесу мовних контактів і розкриття способів адаптації запозичених одиниць у результаті засвоєння мовою нового слова. Проаналізовано наявні методики аналізу лексичних запозичень, які розроблялися представниками структурного підходу (дистрибутивний аналіз, компонентний аналіз, трансформаційний аналіз, опозиційний аналіз, аналіз семантичних полів). Схарактеризовано два види факторів впливу на процеси запозичень у межах сочіологічного підходу: 1) різномінітні сочіальні явища й 2) свідомий вплив суспільства. Виявлено екстралінгвістичні фактори впливу на поповнення словникового складу англійської мови. Окреслено поняття: “лінгвістичне планування", “лінгвістична конструкція”, “лінгвістична політика”. Представлено шкалу аналізу запозичень (С. Г. Томасон), яка прогнозує масштаби інтерференції та білінгвізму (нерегулярні, більш регулярні та інтенсивні контакти). Систематизовано розроблені дослідниками методи для аналізу адаптащії (неадаптащіï) нових слів в англійській мові з урахуванням соиіолінгвістичних і власне мовних процесів.

Ключові слова: запозичення, мовні контакти, лексичні запозичення, структурний і сочіологічний підходи, сочіальні фактори, структурний метод $i$ його методики, адаптація запозичень, інтерференція, білінгвізм, асимілячія запозичень, диглосія. 